\title{
TINJAUAN USAHA BERDASAR ANALISA LAPORAN RUGI LABA SEBAGAI ACUAN PENGAMBILAN KEPUTUSAN STRATEGIS
}

\author{
Arief Saptono ${ }^{1}$ \\ Dosen STMIK Raharja ${ }^{1}$ \\ Jl. Jendral Sudirman No. 40, Modern Cikokol, Tangerang ${ }^{1}$ \\ Email:arief.saptono@raharja.info ${ }^{1)}$
}

\begin{abstract}
ABSTRAK
Aktifitas usaha dengan orientasi profit diperlukan standar untuk mengukur keberhasilanya. Store Operational Income dipakai sebagai indikator penentu keberhasilan di Outlet Burger King, SOI bernilai positif pada laporan Profit and Lost Statement $(P \& L)$ berarti usaha yang kita laksanakan menghasilkan keuntungan.

Pertumbuhan Sales yang baik bila tidak diikuti penerapan sistem manajerial baik akan menjadi kendala terhadap Prosentase Profit yang akan di peroleh. Kenaikan sales sebesar $24 \%$ di tahun 2013 dan peningkatan Revenue sebesar 14,5\% tidak diikuti dengan perolehan persentase pencapaian Bugget Target yang ditetapkan seperti COGS, Gross Profit, dan Store Expenses. Unsur-unsur tersebut adalah pencerminan tingkat kinerja manajemen yang bisa diukur dengan persentase yang sangat mempengaruhi tingkat perolehan SOI. Semakin tinggi Persentase Margin yang diperoleh memungkinkan tingkat SOI yang kita peroleh semakin tinggi. Evaluasi diperlukan untuk merekondisikan strategi yang sedang berjalan agar diperoleh relevansi antara misi perusahaan dengan aspek manajerial ditingkat operasional.

Penerapan kembali Alternatif Strategi sebagai hasil dari analisa matrix SWOT merupakan pilihan efektif untuk bisa mereduksi permasalahan-permasalahan serta kendala operasional yang menyangkut aspek-aspek bisnis yang ada seperti kepuasan pelanggan, operasional, keuangan dan SDM.

Kata kunci: SOI, $P \&$ L, dan Alternatif Strategi.
\end{abstract}

\begin{abstract}
Business activity with profit orientation required standard to measure its success. Store Operational Income is used as a critical success indicator in Outlet Burger King, a positive SOI on the Profit and Lost Statement $(P \& L)$ report means our business is doing a profit.

Sales growth is good if not followed by the implementation of a good managerial system will be a constraint on the percentage of Profit to be earned. A 24\% increase in sales in 2013 and a $14.5 \%$ increase in Revenue are not followed by achieving a target percentage of target Bugget attainments such as COGS, Gross Profit and Store Expenses. These elements are a reflection of the level of performance management that can be measured by a percentage that greatly affects the SOI acquisition rate. The higher Percentage of Margin obtained allows the higher SOI level we get. Evaluation is needed to reconcile the ongoing strategy to obtain the relevance between corporate mission and managerial aspects at the operational level.

Redefining Alternative Strategies as a result of the SWOT matrix analysis is an effective option for reducing operational issues and constraints related to existing business aspects such as customer satisfaction, operations, finance and human resources.
\end{abstract}

Keywords: SOI, $P \&$ \& and Alternative Strategy.

\section{PENDAHULUAN}

Salah satu instrumen utama dalam menganalisis kondisi usaha adalah dengan menggunakan analisia keuangan, karena dengan analisis ini akan terlihat kondisi nyata dari 
perusahaan. Ukuran keberhasilan suatu usaha bisa dilihat dari laporan keuangan, kemampuan perusahaan untuk menghasilkan laba dalam proses operasionalnya merupakan tujuan dari fokus kegiatan usaha. Laba yang dihasilkan merupakan pencerminan dari prestasi yang didapat oleh perusahaan tersebut.

Masalah-masalah yang sering dihadapi manager di lapangan diantaranya adalah a. Masalah penjualan yang menurun serta peningkatan harga maupun tingkat keluaran produk; b. Biaya produksi yang bertambah yang berasal dari proses produksi maupun dari pihak vendor sebagai pemasok produk; c. Masalah investasi dan pendanaan; d. Tingkat persediaan produk; e. Tingkat produktivitas yang menurun; f. Pemasaran produk dan pemilihan media sebagai sarana promosi yang tepat dan efisien.

Tugas manager adalah membuat keputusan yang langsung berkaitan pada masalahmasalah yang terkait dengan operasional bisnisnya. Masalah yang timbul pasti berbeda antara satu outlet dengan outlet yang lain sehingga keputusan yang diambil memerlukan ukuran sebagai patokan untuk pencapaian tujuan oleh perusahaan secara optimal. Manajemen yang baik akan menitik beratkan fokus kegiatan operasionalnya setiap hari, prosedur kerja secara terus menerus dan terkontrol memungkinkan kegiatan operasional mendekati pada tingkat Teoritical yang maksimal artinya secara teori sudah dalam jalur mendekati yang sebenarnya.

\section{RUMUSAN MASALAH}

Dalam penelitian ini rumusan masalah yang di ajukan sebagai berikut:

1. Sejauh mana Laporan Rugi Laba memberikan kontribusi terhadap data informasi yang dihasilkan?

2. Sejauh mana kemampuan analisa manajemen dalam pemecahan masalah dengan menggunakan data laporan?

3. Apakah terdapat pengaruh terhadap kinerja manajemen dengan mengacu pada keputusan berdasarkan data yang dihasilkan dari proses produksi?

\section{KAJIAN TEORI}

\section{Iplementasi Strategi}

Komponen keberhasilan organisasi dilihat dari sisi manajemen strategi menurut David (2009) terdiri dari 3 tahap yaitu:

a). Perumusan strategi, termasuk mengembangkan misi bisnis, mengenali peluang dan ancaman eksternal perusahaan, menetapkan kekuatan dan kelemahan internal, menetapkan objektif jangka panjang, menghasilkan strategi alternatif dan memilih strategi tertentu untuk dilaksanakan.

b). Implementasi strategi, karyawan dituntut untuk menetapkan objektif tahunan memperlengkapi dengan kebijakan, memotivasi karyawan dan mengalokasikan sumber daya sehingga strategi yang dirumuskan dapat dilaksanakan, mengimplementasi termasuk mengembangkan budaya mendukung strategi, menciptakan struktur organisasi yang efektif, mengubah arah usaha pemasaran, menyiapkan anggaran, mengembangkan dan memanfaatkan sistem informasi, dan menghubungkan kompensasi karyawan dengan prestasi organisasi. 
c). Evaluasi strategi, merupakan kegiatan yang sifatnya mendasar dimana perusahaan melakukan peninjauan terhadap faktor-faktor eksternal dan internal yang menjadi dasar strategi mengukur prestasi dan mengambil tindakan korektif, jika strategi tertentu tidak berfungsi lagi dengan baik.

\section{Evaluasi Strategi}

Evaluasi menurut Husein Umar (2002): "suatu proses untuk menyediakan informasi tentang sejauh mana suatu kegiatan tertentu telah dicapai, bagaimana perbedaan pencapaian itu dengan suatu standar tertentu untuk mengetahui apakah ada selisih di antara keduanya, serta bagaimana manfaat yang telah dikerjakan itu bila dibandingkan dengan harapan-harapan yang ingin diperoleh".

Menurut David (2009), evaluasi strategi terdiri dari tiga aktivitas dasar, yaitu:

a. Meneliti dasar-dasar dari suatu strategi.

b. Membandingkan hasil yang diharapkan dengan kenyataan.

c. Mengambil tindakan korektif untuk memastikan bahwa prestasi sesuai dengan rencana.

Proses evaluasi erat kaitannya dengan usaha pengendalian kegiatan yang sedang berjalan. Biasanya dipandang sebagai kegiatan empat unsur yang saling berkaitan, yaitu:

a. Menggariskan sasaran prestasi kerja, standar, dan batas toleransi untuk tujuan, strategi, dan rencana pelaksanaan.

b. Mengukur posisi yang sesungguhnya sehubungan dengan sasaran pada suatu waktu tertentu.

c. Menganalisis penyimpangan dari batas toleransi yang dapat diterima.

d. Melaksanakan modifikasi jika dirasa perlu dan/atau layak

Manajemen stategis menurut Wheelen \& Hunger (2000) adalah satu set dari keputusan manajerial dan tindakan yang menentukan performa jangka panjang sebuah perusahaan. Termasuk didalamnya adalah monitor lingkungan (eksternal dan internal), formulasi (strategis atau rencana jangka panjang), implementasi serta evaluasi dan kontrol/pengendalian sebagaimana ditunjukkan Gambar 1.

Gambar 1. Elemen dasar dari proses manajemen strategis

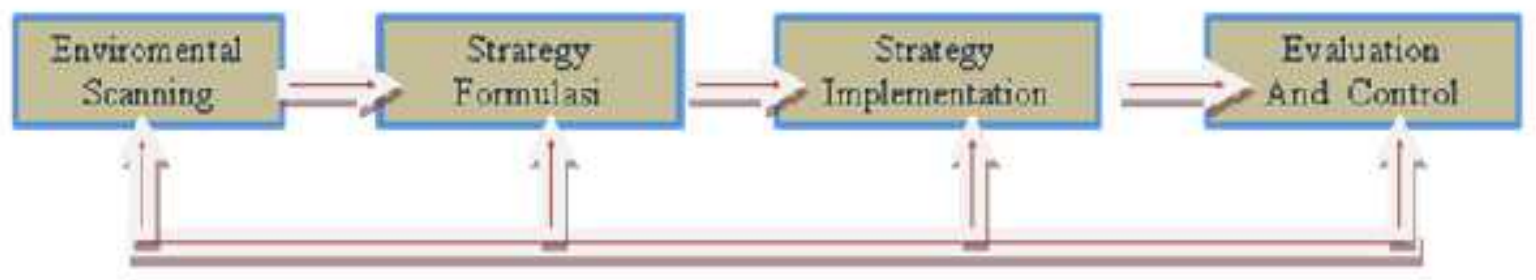

Sumber: Thomas L. Wheelen \& David Hunger (2000)

Proses manajemen strategis meliputi tahapan sbb : 1). Analisis lingkungan. Analisis lingkungan dengan memperhatikan, mengevaluasi dan menyebarkan informasi dari 
lingkungan eksternal dan internal pada pihak manajemen perusahaan. Tujuannya adalah untuk mengidentifikasi faktor-faktor strategis, yaitu elemen eksternal dan internal yang akan menentukan masa depan perusahaan. 2). Formulasi strategi. Formulasi strategi adalah pengembangan dari rencana jangka panjang untuk efektivitas manajemen dalam menentukan peluang dan ancaman serta kekuatan dan kelemahan perusahaan. Termasuk didalamnya mengidentifikasi misi perusahaan, menjelaskan tujuan yang akan dicapai, mengembangkan strategi dan menentukan kebijakan perusahaan. 3). Implementasikan strategi. Implementasi adalah proses dimana strategi dan kebijakan dilaksanakan dengan mengembangkan program anggaran dan prosedur. Proses ini melibatkan keseluruhan budaya, struktur dan sistem manajemen yang ada di dalam suatu organisasi. Implementasi strategi biasanya dilakukan pada manajemen tingkat menengah dan manajemen tingkat bawah dengan pengawasan dari manajemen pusat. 4). Evaluasi dan pengendalian. Merupakan proses dimana aktivitas perusahaan dan hasil kinerja diperhatikan, sehingga kinerja aktual dapat dibandingkan dengan kinerja yang diinginkan. Manajer dalam semua tingkatan menggunakan hasil informasi untuk melakukan tindakan perbaikan dan menyelesaikan masalah.

Pada intinya, proses evaluasi dan pengendalian disusun untuk memastikan bahwa kesenjangan antara tujuan yang diharapkan dan yang diinginkan akan tertutup sesuai dengan strategi tersebut. Sistem pengendalian strategis (Hill \& Jones, 2009) ditujukan untuk: (1) menetapkan standard dan target lawan kinerja yang dapat diukur; (2) menciptakan sistem untuk mengukur dan memantau kinerja secara regular; (3) membandingkan kinerja actual dengan target; dan (4) evaluasi hasil dan ambil tindakan perbaikan yang diperlukan.

\section{Indikator Kinerja}

Indikator kinerja menurut Mahsun (2006) adalah ukuran kuantatif dan/atau kualitatif yang menggambarkan tingkat pencapaian suatu sasaran atau tujuan yang telah ditetapkan. Ada beberapa aspek bisnis penting untuk dievaluasi, akan tetapi aspek-aspek tersebut dapat dikembangkan lagi sesuai dengan kebutuhan evaluasi di perusahaan. Diantaranya seperti aspek pelanggan, aspek operasional, aspek keuangan dan aspek sumber daya manusia.

a. Aspek pelanggan Dalam aspek ini ada beberapa hal yang menjadi pertimbangan perusahaan, sesuai dengan kebutuhan dari perusahaan maka indikator yang digunakan adalah: Customer satisfaction, menggambarkan tercapainya pemenuhan harapan konsumen terhadap produk/jasa yang digunakan. Tolok ukur ini menunjukkan seberapa baiknya perusahaan memperlakukan konsumen yang ada. Dengan terwujudnya kepuasan konsumen, memberikan keuntungan jangka panjang bagi perusahaan antara lain dengan adanya pembelian kembali terhadap produk/jasa dan juga efisiensi biaya promosi. Cara mengukur kepuasan konsumen dapat dilakukan dengan melihat jumlah pelanggan puas dibagi dengan total pelanggan atau dengan melakukan survei terhadap konsumen.

b. Aspek operasional dengan aspek ini memungkinkan perusahaan untuk mengetahui seberapa baik bisnis mereka berjalan dan apakah produk/jasa yang ditawarkan sesuai dengan spesifikasi konsumen. Efektivitas operasional dipengaruhi oleh faktor-faktor operasional yang disebut dengan keputusan-keputusan operasi, yaitu faktor: mutu, 
desain barang/ jasa, desain proses dan kapasitas, seleksi lokasi, manusia dan sistem kerja, manajemen dan rantai-pasokan, persediaan, penjadwalan dan pemeliharaan.

c. Aspek keuangan Rasio Profitabilitas, digunakan untuk mengukur kemampuan perusahaan dalam mendapatkan laba dari setiap penjualan yang dilakukan. Marjin laba kotor, mencerminkan mark-up terhadap harga pokok penjualan selain mencerminkan kemampuan manajemen untuk meminimalisasi harga pokok penjualan dalam hubungannya dengan penjualan yang dilakukan perusahaan.

Marjin laba kotor $=\underline{\text { Laba Kotor }}$

Penjualan Bersih

c. Aspek sumber daya manusia Karyawan sebagai ujung tombak perusahaan memegang peranan penting bagi keberlangsungan perusahaan. Penempatan SDM pada posisi yang tepat akan membantu terwujudnya tujuan perusahaan. Pengukuran kinerja atas SDM dilakukan secara berkala dengan harapan adanya peningkatan kinerja karyawan yang secara otomatis akan menaikkan produktivitas perusahaan. Kinerja SDM dapat diukur dengan mempertimbangkan aspek-aspek seperti: kualitas pekerjaan, kehadiran, turnover, produktivitas, keselamatan dan kesehatan kerja dan lainnya.

\section{Analisa SWOT}

Menurut Fahmi (2013:252), "SWOT adalah singkatan dari strengths (kekuatan), weaknesses (kelemahan), opportunities (peluang), dan thereats (ancaman), dimana SWOT ini dijadikan sebagai suatu model dalam menganalisis suatu organisasi yang berorientasi profit dengan tujuan utama untuk mengetahui keadaan organisasi tersebut secara lebih komprehensif.

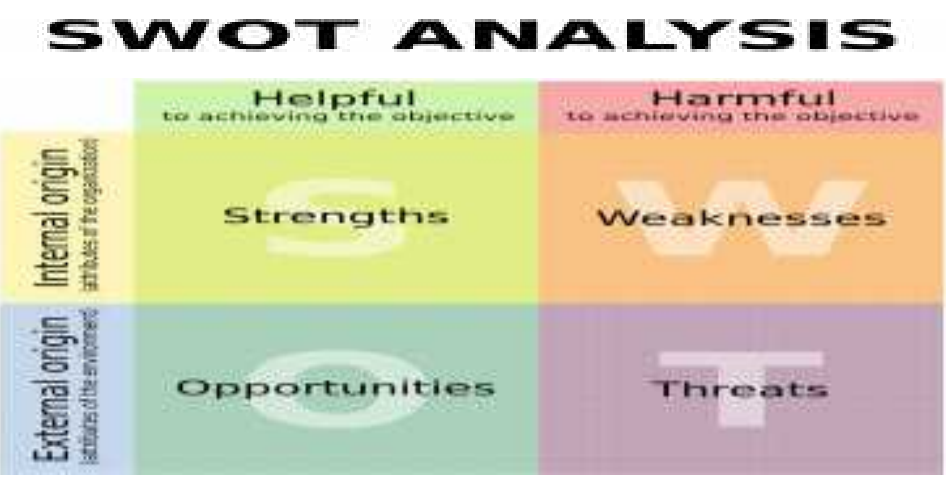

Gambar 2. SWOT Analysis

Menurut Hendro (2011:289), "Banyak manfaat bila kita melakukan analisa masalah secara SWOT yaitu Strength, Weakness, Oppurtunity, and Threats sebelum diambil keputusan untuk dibandingkan dengan pengambilan keputusan tanpa mempertimbangkan dan melakukan analisa masalah." manfaatnya adalah :

a. Dapat diambil tindakan manajemen yang tepat sesuai dengan kondisi.

b. Untuk membuat rekomendasi.

c. Informasi lebih akurat.

d. Untuk mengurangi resiko akibat dilakukannya keputusan yang berkali-kali (double decision).

e. Menjawab hal yang bersifat intuitif atas keputusan yang bersifat emosional. 


\section{METODOLOGI PENELITIAN Objek Penelitian}

Objek yang diteliti dalam penelitian ini adalah laporan Rugi Laba ( $P \&$ \& Statment) keuangan Burger King Karawaci. Jenis data yang dipakai dalam penelitian ini adalah data sekunder. Periode penelitian yang digunakan dengan membandingkan data dari bulan Januari sampai dengan Juli ditahun 2012-2013.

\section{Metode Pengumpulan Data}

Pengumpulan data dilakukan melalui dokumentasi, yaitu pengambilan data yang diperoleh dari laporan keuangan publikasi bulanan dan data penunjang yang terkait untuk selanjutnya diolah oleh peneliti.

Proses Evaluasi strategi dalam penelitian ini mengikuti kerangka bepikir sebagai berikut :

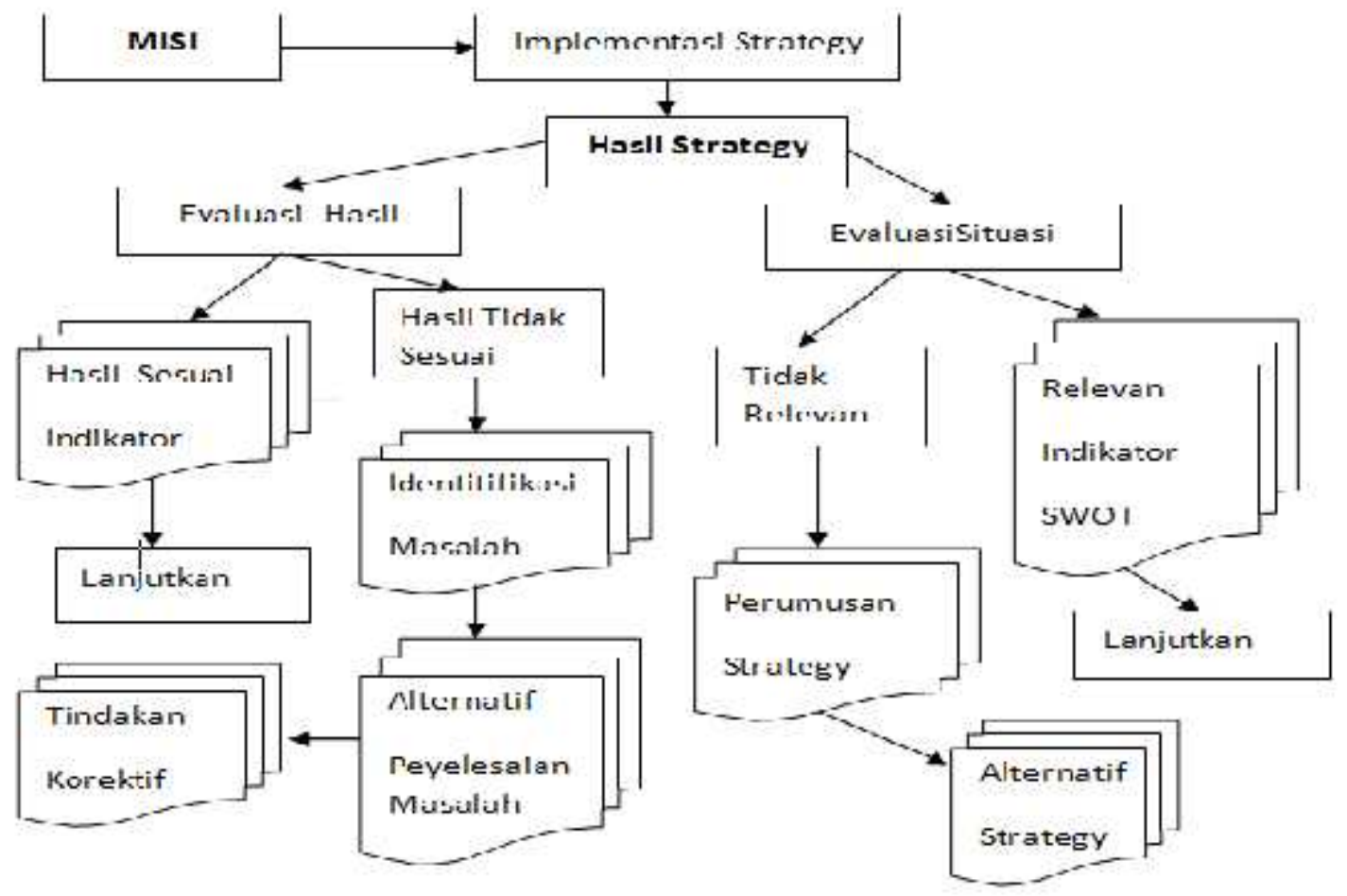

Gambar 3. Kerangka Pemikiran

Data yang akurat sebagai bahan evaluasi dibutuhkan untuk mendapatkan informasi, setelah data tersebut dianalisa kemudian Kegiatan berlanjut dengan membandingkan antara data fakta dengan data standar atau target pencapaian perusahaan dengan kata lain data dibandingkan secara Theoritical.

\section{HASIL PENELITIAN}

\section{Evaluasi Hasil Laporan}

Perusahaan retail seperti Burger King dalam proses kegiatannya memerlukan suatu informasi yang secara berkala dan berkesinambungan sebagai dasar informasi atau acuan dalam proses pengambilan keputusan. Informasi yang didapat dari proses analisa mencerminkan hubungan antara proses kegiatan usaha dengan pelaku kegiatan usaha atau pihak pengelola dalam hal ini adalah manajemen, faktor manajemen menjadi sangat penting 
dalam menentukan arah proses kegiatan usaha agar diperoleh profitabilitas yang optimal. Hasil penelitian diperoleh data seperti yang tertera pada tabel 1.

\begin{tabular}{|c|c|c|c|c|c|c|c|}
\hline \multicolumn{8}{|c|}{ PROFIT \& LOSS STA TEMENT - B.KING SUPER MALL KA WARACI } \\
\hline \multirow[t]{2}{*}{ IN MIO RUPIAH } & \multicolumn{2}{|c|}{ YTD JULY' 13} & \multicolumn{2}{|c|}{ YTD JULY' 12} & \multirow{2}{*}{$\begin{array}{c}\% \\
\text { GROWT }\end{array}$} & \multicolumn{2}{|c|}{ B UDG ET YTD' 13} \\
\hline & amount & $\% N S$ & amount & \% NS & & amount & $\% N S$ \\
\hline DA YS OPERA TION & 212 & & 213 & & & 212 & \\
\hline ADT & 418 & & 337 & & & 372 & \\
\hline $\begin{array}{l}\text { AT } \\
\text { Total Revenue }\end{array}$ & $\begin{array}{r}40.727 \\
\mathbf{3 . 6 1 1}\end{array}$ & $100,0 \%$ & $\begin{array}{r}43.860 \\
3.152\end{array}$ & $\mathbf{1 0 0 , 0 \%}$ & $15 \%$ & $\begin{array}{r}\text { 43.000 } \\
3.388\end{array}$ & $100,0 \%$ \\
\hline Cost of Goods Sold & 1.697 & $47,0 \%$ & 1.411 & $44,8 \%$ & $20 \%$ & 1.389 & $41,0 \%$ \\
\hline Royalty & 199 & $5,5 \%$ & 173 & $5,5 \%$ & $15 \%$ & 186 & $5,5 \%$ \\
\hline Gross Profit & 1.716 & $47,5 \%$ & 1.568 & $49,7 \%$ & $9 \%$ & 1.813 & $53,5 \%$ \\
\hline & $47,5 \%$ & & $49,7 \%$ & & & $53,5 \%$ & \\
\hline Store Expense & 1.978 & $54,8 \%$ & 1.818 & $57,7 \%$ & $9 \%$ & 2.134 & $63,0 \%$ \\
\hline Rental Expense & $279^{F}$ & $7,7 \%$ & 243 & $7,7 \%$ & $15 \%$ & 261 & $7,7 \%$ \\
\hline $\begin{array}{l}\text { - Rental } \\
\text { - Commission }\end{array}$ & 279 & $\begin{array}{l}7,7 \% \\
0,0 \%\end{array}$ & 243 & $\begin{array}{l}7,7 \% \\
0,0 \%\end{array}$ & $15 \%$ & 261 & $\begin{array}{l}7,7 \% \\
0,0 \%\end{array}$ \\
\hline Rental Income & & $\mathbf{0 , 0 \%}$ & & $\mathbf{0 , 0} \%$ & & & $\mathbf{0 , 0} \%$ \\
\hline Payroll & 562 & $15,6 \%$ & 473 & $15,0 \%$ & $19 \%$ & 695 & $20,5 \%$ \\
\hline Depr \& Amortization & 300 & $8,3 \%$ & 295 & $9,3 \%$ & $2 \%$ & 314 & $9,3 \%$ \\
\hline Advertising \& Promotion & 140 & $3,9 \%$ & 158 & $5,0 \%$ & $-11 \%$ & 169 & $5,0 \%$ \\
\hline Telepione & 12 & $0,3 \%$ & 11 & $0,4 \%$ & $3 \%$ & 8 & $0,2 \%$ \\
\hline Utilities & 477 & $13,2 \%$ & 438 & $13,9 \%$ & $9 \%$ & 478 & $14,1 \%$ \\
\hline Transport \& Travelling & 21 & $0,6 \%$ & 20 & $0,6 \%$ & $7 \%$ & 19 & $0,6 \%$ \\
\hline Call Centre \& Delivery & & $\mathbf{0 , 0 \%}$ & & $\mathbf{0 , 0} \%$ & & & $\mathbf{0 , 0 \%}$ \\
\hline Credit Card Commissiou & 5 & $\mathbf{0 , 1} \%$ & 5 & $0,2 \%$ & $-5 \%$ & 5 & $0,2 \%$ \\
\hline Store Supplies & 53 & $1,5 \%$ & 57 & $\mathbf{1}, \mathbf{8 \%}$ & $-7 \%$ & 58 & $1,7 \%$ \\
\hline Repair \& Maintenance & 107 & $3,0 \%$ & 102 & $3,2 \%$ & $5 \%$ & 108 & $3,2 \%$ \\
\hline Insurance & 4 & $0,1 \%$ & 5 & $0,2 \%$ & $-26 \%$ & 3 & $0,1 \%$ \\
\hline Legal \& Permit & 4 & $0,1 \%$ & & $\mathbf{0 , 0} \%$ & & & $\mathbf{0 , 0} \%$ \\
\hline Sundries & 13 & $0,4 \%$ & 11 & $0,3 \%$ & $18 \%$ & 16 & $0,5 \%$ \\
\hline Store Income & -262 & $-7,3 \%$ & -250 & $-7,9 \%$ & $5 \%$ & -321 & $-9,5 \%$ \\
\hline Pre-opening Store Exp & & $\mathbf{0 , 0} \%$ & & $\mathbf{0 , 0} \%$ & & & $\mathbf{0 , 0 \%}$ \\
\hline EB ITDA & 38 & $1,1 \%$ & 45 & $1,4 \%$ & $-15 \%$ & -7 & $-0,2 \%$ \\
\hline
\end{tabular}

Tabel 1. Laporan P \& L Statemen (dalam Miliar dan persentase)

Adanya peningkatan kunjungan Customer sebesar $24 \%$ dibanding tahun 2012 pada periode yang sama dari januari sampai Juli tahun 2013 dengan jumlah hari kerja sebanyak 212 (YTD or Year To Day 2013), yaitu dari ADT (Average Day Total Account) sebesar 337 di tahun 2012 menjadi 418 di tahun 2013. ADT adalah nilai rata-rata dari total jumlah transaksi setiap hari. Peningkatan $A D T$ diikuti juga dengan peningkatan Total Revenue atau Total Sales sebesar 14,5\% dari sales Rp 3.152,- di tahun 2012 menjadi Rp. 3.611,- (dalam Miliar) dengan target pencapaian $6.5 \%$ ditahun 2013 artinya peningkatan jumlah kunjungan berpengaruh signifikan (Positif) terhadap pendapatan yang diperoleh. Hal ini bisa dilihat pada tabel 2. 


\begin{tabular}{|l|rrrcr|}
\hline & th. 2012 & th. 2013 & \% Growth & Target Pencapaian 2013 & \% Pencapaian \\
& & & & BUGET TARGET & \multicolumn{1}{c|}{ 2013 } \\
\hline Total Revenue & 3.152 & 3611 & $\mathbf{1 4 , 5 0 \%}$ & 3.388 & $\mathbf{6 , 5 0 \%}$ \\
ATD/ATC & 337 & 418 & $\mathbf{2 4 \%}$ & 372 & $\mathbf{1 2 , 4 0 \%}$ \\
AT/ AC & 43860 & 40727 & $\mathbf{- 7 , 1 0 \%}$ & 43000 & $\mathbf{- 5 , 2 8 \%}$ \\
\hline
\end{tabular}

Tabel 2. Total Revenue, TC, AC 2013 dan 2013

Pertumbuhan sales di tahun 2013 disebabkan oleh komitmen dari perusahaan untuk terus menjaga kualitas produk dengan selalu berorientasi pada kepuasan pelanggan ( Customer Satisfaction) yang menjadi modal dasar bagi perusahaan yang bergerak di bidang jasa makanan, hal ini berdampak pada semakin banyak konsumen yang loyal terhadap produk yang ditawarkan baik produk reguler maupun produk inovasi terbaru. Kotler dan Armstrong (2008) mengatakan kualitas produk merupakan karakteristik produk atau jasa yang bergantung pada kemampuannya untuk memuaskan kebutuhan pelanggan yang dinyatakan atau diimplikasikan.

Menurut Sattar dan Beenish Sattar (2012) bahwa keuntungan dari setiap perusahaan tergantung dari seberapa banyak konsumen yang loyal serta adanya konsumen yang tetap dan melakukan pembelian berulang kali. Kotler dan Armstrong (2012) mengatakan, konsumen yang merasakan kepuasan akan melakukan pembelian kembali dan memberitahukan kepada orang lain mengenai pengalaman mereka yang menyenangkan.

Peningkatan Sales tidak diikuti dengan meningkatnya Average Total Count (AT/ AC) ditahun 2013 sebesar $(-7,10 \%)$ artinya bahwa peningkatan Revenue belum diikuti oleh peningkatan Average Count (AC) hal ini bisa dilihat dari perolehan angka AC ditahun 2013 (Rp. 40.727,-) masih dibawah / rendah bila dibandingkan dengan tahun 2012 sebesar (Rp. 43.860,-), demikian juga dengan pencapaian $A C(-5,28 \%)$ masih dibawah Buget Target perusahaan sebesar Rp. 43.000,-sehingga persentase pencapaian target Revenue belum berimplikasi positif terhadap $A T / A C$ target.

\begin{tabular}{l|c|c|c|c|c|} 
& th. 2012 & th. 2013 & $\%$ & BUGET T ARGET & Target \\
\hline & & & Growth & YTD 2013 & Pencapaian \\
\hline Total Revenue & 3.152 & 3.611 & & 3.388 & \\
\hline COGS & $44,80 \%$ & $47,00 \%$ & $20 \%$ & $41,00 \%$ & $-6 \%$ \\
\hline Royalty & 173 & 199 & & 186 & \\
\hline Gross Profit & $47,50 \%$ & $49,70 \%$ & $9 \%$ & $53,50 \%$ & $-3,80 \%$ \\
\hline Store Expenses & $57,70 \%$ & $54,80 \%$ & $9 \%$ & $63 \%$ & $8,20 \%$ \\
\hline \multicolumn{2}{l|}{ Tabel 3. COGS, GP dan Store Expenses } & & & & \\
\hline
\end{tabular}

Target yang ditetapkan ditahun 2013 belum tercapai bila dilihat dari persentase COGS (Cost Of Good Sold), GP (Gross Profit), Store Expenses atau Uncountrolable Expenses. COGS (-6 \%) dari Buget target sebesar $41 \%$ artinya bahwa selama tahun 2013. Faktorfaktor yang bisa menyebabkan kenaikan biaya sehingga berakibat pada tidak terpenuhinya target COGS diantaranya tingkat persediaan produk yang bisa dilihat secara Theoritical dari harga Food dan Papper, Condiment Food and Paper, penggunaan Shortening, pengelolaan 
Waste Product serta Variance Product. Persentase COGS ideal dapat menjadi tolak ukur kinerja manajemen artinya Persentase hasil $C O G S$ yang mendekati nilai ideal dari persentase COGS secara Theoritical menunjukkan kinerja yang baik. Faktor- faktor tersebut lebih banyak di pengaruhi oleh aktifitas pengelola produksi dalam hal ini adalah manajemen. Philip Kotler (2007), mutu atau kualitas adalah keseluruhan fitur dan sifat produk atau pelayanan yang berpengaruh pada kemampuannya untuk memuaskan kebutuhan yang dinyatakan atau yang tersirat. Menurut Johanes Supranto (2001), "Sebuah kata yang bagi penyedia jasa merupakan sesuatu yang harus dikerjakan dengan baik. Aplikasi kualitas sebagai sifat dari penampilan produk atau kinerja merupakan bagian utama dari strategi perusahaan dalam rangka meraih keunggulan yang berkesinambungan, baik sebagai pemimpin pasar ataupun sebagai strategi untuk terus tumbuh.

Store Operating Income (SOI) adalah pendapatan bersih sebagai hasil dari proses opesional bisnis selama kurun waktu tertentu. Ukuran ini digunakan oleh Outlet Burger King yang terdapat pada laporan Profit and Lost report $(P \& L)$. Pada tingkat kegiatan usaha yang dilakukan Beberapa faktor yang berakibat pada persentase margin yang diperoleh, semakin tinggi Persentase margin yang diperoleh memungkinkan tingkat SOI yang kita peroleh semakin tinggi. Countrolable Expenses merupakan bagian yang sangat mempengaruhi tingkat persentase perolehan SOI. Store Operational Income banyak dipakai sebagai indikator penentu keberhasilan suatu usaha, SOI bernilai positif berarti usaha yang kita laksanakan menghasilkan keuntungan.

Berdasarkan hasil penelitian faktor yang bisa kita optimalkan dalam kegiatan bisnis untuk meningkatkan tingkat persentase profitabilitas adalah dengan memaksimalkan tingkat input atau pemasukan di Top Line (Laporan Rugi laba) dengan mengoptimalkan pemasukan Sales melalui kegiatan marketing yang dilakukan secara terprogram dan berkala disamping itu mengpotimalkan kinerja manajemen untuk menunjang proses kegiatan bisnis yang yang sedang berjalan dan pada akhirnya diharapkan proses tersebut berimbas pada meningkatnya persentase Sales sebagai hasil dari proses pengotimalan pengeluaran pada store expenses. Laba menjadi ukuran keberhasilan suatu usaha yang profit motif, dengan laba perusahaan dapat dengan mudah mengembangkan bisnisnya. Ukuran keberhasilan menghasilkan laba dapat dilihat dari tinggi rendahnya profit margin serta tingkat pengembaliannya yang disebut ROI (J. Gitman, 1997 : 34).

\section{Relevansi Hasil Strategi}

Hasil Evaluasi merupakan suatu proses untuk menyediakan informasi tentang sejauh mana suatu kegiatan tertentu telah dicapai, bagaimana perbedaan pencapaian itu dengan suatu standar tertentu untuk mengetahui apakah ada perbedaan atau selisih diantara target dan hasil yang diperoleh secara riil, serta penentuan langkah strategi apa yang paling sesuai untuk menindak lanjuti atas perbedaan tersebut. Kegiatan evaluasi membutuhkan data untuk dianalisis dengan alat-alat yang relevan untuk menghasilkan informasi yang sesuai dengan kebutuhan.

Pada intinya, proses evaluasi dan pengendalian disusun untuk memastikan bahwa kesenjangan antara tujuan yang diharapkan dan yang diinginkan akan tertutup sesuai dengan strategi tersebut. Sistem pengendalian strategis (Hill \& Jones, 2009) ditujukan untuk: (1) menetapkan standard dan target lawan kinerja yang dapat diukur; (2) menciptakan sistem untuk mengukur dan memantau kinerja secara regular; (3) membandingkan kinerja actual dengan target; dan (4) evaluasi hasil dan ambil tindakan perbaikan yang diperlukan. 
Beberapa aspek yang paling menunjang dan berpotensi sebagai faktor dalam menentukan pencapaian sasaran dari tujuan perusahaan yang ditetapkan untuk memenuhi kebutuhan akan evaluasi diantaranya adalah aspek pelanggan, aspek operasional, aspek keuangan dan aspek SDM.

Aspek pelanggan adalah aspek terpenting karena pada aspek ini proses pertumbuhan suatu bisnis akan terlihat, dari sisi produk tingkat daya serap produk sebagai pemenuhan atas kebutuhan pelanggan. Semakin tinggi tingkat daya serap menunjukkan tingkat kemampuan produk untuk bisa diterima oleh pasar. Produk Burger King adalah produk yang sudah cukup dikenal pada level pelanggan atau customer dengan segmen menengah ke atas. Faktor Brand Imaze dari produk tersebut yang sudah mendunia memudahkan dalam penetrasi pasar, hal ini merupakan kelebihan yang dimiliki oleh Outlet Burger King. Tingkat Kepuasan akan produk yang ditawarkan adalah jaminan dari suatu komitmen bisnis, hal ini bisa dilihat dari bagaimana team manajemen mempelakukan Customer sebagai komitmen bisnis dengan menerapkan Customer Satisfaction.

Aspek operasional merupakan aspek pendukung yang akan sangat mempengaruhi tingkat kepuasan pelanggan apabila faktor-faktor operasional seperti mutu atau kualitas produk, desain barang/ jasa, desain proses dan kapasitas, seleksi lokasi, manusia dan sistem kerja, manajemen dan rantai-pasokan, persediaan, penjadwalan dan pemeliharaan. Dari data yang ada faktor diatas sudah sejak awal berdirinya outlet sudah menjadi fokus dari perusahaan, seperti penerapan SOP (Standart Operating Procedure) pada seleksi karyawan, sistem manajemen kerja, sistem kerjasama dengan pihak vendor sebagai penyuplai produk untuk mendukung ketersediaan pasokan penjadwalan yang baik. Perencanaan yang matang pada saat bisnis dimulai sudah akan mereduksi kemungkinan- kemungkinan masalah yang akan timbul pada saat operasional bisnis.

Aspek rasio Profitabilitas adalah tujuan dari semua usaha bisnis yang berorientasi pada profit. Faktor luar dan dalam akan mempengaruhi orientasi bisnis. Faktor luar dalam hal ini ada kaitannya sistem pemasaran yang ada masih belum terprogram dengan baik. Pemasaran produk yang terencana dan terukur dengan baik akan mendukung tingkat rasio Profitabilitas. Faktor dalam yang berkaitan dengan manajemen operasional masih perlu ditingkatkan dari sisi Standar dan prosedur kerja hal ini berkaitan erat dengan hasil kerja atau kualitas kerja. Pada tabel 3 memperlihatkan bahwa COGS, GP dan Store Expenses pada YTD 2013 masih belum standart bila di bandingkan dengan Bugget Target 2013.

Aspek SDM (Sumber Daya Manusia) masih perlu di jadikan Consern pihak manajemen ini berkaitan erat dari data yang ada yang ada hubungannya dengan Turn Over dari karyawan yang tinggi demikian juga dengan pembayaran karyawan atau Payroll yang masih diatas standart Bugget Target tahun 2013. Turn Over yang tinggi diakibatkan sistem kerja yang ada dan berkakibat pada kenaikan biaya Training, karena setiap terjadi pengurangan karyawan yang diakibatkan karyawan mengundukan diri atau keluar dengan sendirinya akan berkakibat kurangnya karyawan, sehingga harus menghiring karyawan baru, yang selanjutnya melalui proses training terlebih dulu sebelum Running.

Diperlukan Reanalisa atau kajian ulang terhadap strategi bisnis yang sudah ada untuk selanjutnya ditetapkan ulang alternatif dari strategi baru dan mengindetifikasi masalahmasalah yang ada untuk dicari alternatif penyelesaiaannya. Sistem strategi alternatif diperlukan sebagai cara untuk memanfaatkan kembali balikan sebagai masukan untuk perencanaan strategi baru dan sebagai sarana untuk pengecekan/pengujian ganda bahwa 
strategi yang dipilih sudah konsisten, tepat, dan dapat dijalankan dengan analisis internal dan eksternal serta rencana untuk melaksanakannya. Proses penentuan Action Plan berguna untuk memastikan bahwa kesenjangan antara tujuan yang diharapkan dan yang diinginkan akan terwakili sesuai dengan strategi yang ada.

\section{SWOT Analisis}

Berdasarkan observasi diperoleh analisa SWOT seperti yang tertera pada tabel 4 berikut:

\begin{tabular}{|c|c|}
\hline Strenghts & Wekenesses \\
\hline $\begin{array}{l}\text { 1. Hubunga yang baik dengan Customer. } \\
\text { 2. Kualitas Product dengan Brand imaze yang } \\
\text { cukup terkenal. } \\
\text { 3. Pertumbuhan Sales yang cukup Baik. } \\
\text { 4. Dukungan dari Vendor (Supliyer) yang cukup } \\
\text { baik. } \\
\text { 5. Sistem kerja sudah Berjalan dengan teratur. }\end{array}$ & $\begin{array}{l}\text { 1. Promosi masih kurang. } \\
\text { 2. Turn Over yang tinggi. } \\
\text { 3. Produk mudah ditiru. } \\
\text { 4. Sebagian besar bahan baku masih produk } \\
\text { import. } \\
\text { 5. Trading Area pemasaran masih sempit. }\end{array}$ \\
\hline Opportunities & Threats \\
\hline $\begin{array}{l}\text { 1. Industri Makanan yang akan terus berkembang. } \\
\text { 2. Pertumbuhan ekonomi Yang baik. } \\
\text { 3. Peluang inovasi terhadap variasi product. } \\
\text { 4. Tumbuhnya industri pendukung. }\end{array}$ & $\begin{array}{l}\text { 1. Fluktuasi nilai tukar Rupiah. } \\
\text { 2. Banyak industri sejenis yang tumbuh dan } \\
\text { beragam. } \\
\text { 3. Adanya pesaing baru dengan konsep yang } \\
\text { inovatif. }\end{array}$ \\
\hline
\end{tabular}

Tabel 4. Analisa SWOT tahun 2013

Situasi yang ada diperoleh analisa SWOT yang menjadi ukuran analisa Relevansi strategi bisnis yang sedang berjalan. Analisa SWOT dapat dijadikan sebagai tolak ukur dari Relevansi Strategis yang selanjutnya akan digunakan untuk menentukan strategi alternatif jika diperlukan. Keakuratan data informasi tentang laporan perusahaan akan sangat menentukan terhadap hasil pengukuran relenvansi strategi karena keberhasilan perusahaan tergantung pada penerapan strategi yang tepat pada situasi yang tepat.

\section{Strategi Alternatif}

Strategi Alternatif merupakan penjabaran strategi baru dari situasi yang didapat dari hasil analisa SWOT, sehingga terdapat Relevansi Strategis antara komponen pembentuk SWOT seperti Strenghts (kekuatan) dipadukan dengan Opportunities (Peluang) atau Weaknesses (kelemahan) dengan Opportunities (peluang) dengan menggunakan matrix SWOT akan diperoleh alternatif-alternatif strategi yang relevan, yang selanjutnya bisa dijadikan patokan atau ukuran untuk menetukan kebijakan strategi pada proses bisnis selanjutnya. 


\begin{tabular}{|c|c|}
\hline Strenghts with Opportunities Strategy (SO) & Weaknesses with Opportunities Strategy (WO) \\
\hline $\begin{array}{l}\text { 1. Menjaga dan Mempertahankan Qualitas } \\
\text { Product } \\
\text { 2. Mempertahankan dan menjaga terciptanya } \\
\text { kerjasama dengan Vendor (Supliyer) } \\
\text { 3. Memperbanyak Variasi Product untuk } \\
\text { mendukung peningkatan pertumbuhan } \\
\text { sales }\end{array}$ & $\begin{array}{l}\text { 1. Memperluas jangkauan pemasaran dengan melakukan } \\
\text { promosi untuk meningkatkan persentase pertumbuhan } \\
\text { sales. } \\
\text { 2. Meningkatkan pengawasan yang ketat terhadap } \\
\text { pengeluaran yang akan mempengaruhi formulasi dari } \\
\text { laporan Rugi Laba pada Store Expenses. } \\
\text { 3. Retraining untuk meningkatkan kinerja karyawan }\end{array}$ \\
\hline Strenght with Threats Strategy (ST) & Weaknesses with Threats Strategy (WT) \\
\hline $\begin{array}{l}\text { 1. Memperlebar Expansi, } \\
\text { Kerjasama Customer dengan memberikan } \\
\text { kemudahan dalam pelayanan (Voucer,GJ, } \\
\text { Diskon Product) secara terprogram dan } \\
\text { terukur. } \\
\text { 2. Mengoptimalkan Team marketing untuk } \\
\text { membantu dalam memakimalkan } \\
\text { pertumbuhan Sales. }\end{array}$ & $\begin{array}{l}\text { 1. Menekan penggunaan bahan baku yang dapat } \\
\text { mempengaruhi perolehan margin agar diperoleh GF } \\
\text { (Gross Profit) yang baik ( BUGGET TARGET) } \\
\text { 2. Memaksimalkan pengawasan produk dengan } \\
\text { mengoptimalkan persentase COGS untuk } \\
\text { memaksimalkan SOI. } \\
\text { 3. Memperbaharui Formulasi wilayah pemasaran produk } \\
\text { ( Trading Area) }\end{array}$ \\
\hline
\end{tabular}

Tabel 5. Alternatif Strategy (Analisa Matrik SWOT)

Hasil dari implementasi strategi alternatif tetap harus dibandingkan dengan standar yang ada sebagai tolok ukur tertentu penilaian evaluasi selanjutnya. Evaluasi strategi secara terusmenerus bisa digunakan perusahaan untuk mengukur kemajuan bisnis yang sedang berlangsung.

\section{KESIMPULAN}

Berdasarkan hasil evaluasi kinerja strategi dan tinjauan situasi Burger King Karawaci dapat ditarik kesimpulan sebagai berikut:

1. Data laporan Rugi Laba sebagai ukuran kuantitatif adalah instrumen untuk mengukur tingkat kinerja manajemen ( Pertumbuhan Sales, Positif, COGS sesuai Teori GP,Store Expenses atau Controlable Expenses sesuai Bugget Standart).

2. Pemecahan masalah dengan Analisis SWOT diperlukan untuk menentukan Alternatif Strategi manajerial dalam mengoptimalkan kinerja manajemen.

3. Implementasi Alternatif strategi sebagai hasil Evaluasi kinerja diaharapkan berdampak positif untuk meningkatkan pertumbuhan profit bisnis.

\section{DAFTAR PUSTAKA}

[1] David, Fred. R .2009. Strategic Management: Concepts and Cases, 12th edition, PrenticeHall

[2] Fahmi, dkk. 2013. "Analisis SWOT". Jakarta: Gramedia

[3] Husein Umar .2002. Evaluasi Kinerja Perusahaan, Gramedia Pustaka Utama.

[4] Hendro, M.M. 2011. "Dasar-Dasar Kewirausahaan”. Surabaya: Erlangga.

[5] Hill, Charles W. L. and Gareth r. Jones .2009. Theory of Strategic Management With Cases, 8th ed., South-Western Cengage Learning 
[6] Kotler, Philip dan Kevin Lane Keller, 2007, Manajemen Pemasaran, Edisi 12, Jilid 2, Terjemahan oleh Benyamin Molan, Jakarta: PT Indeks.

[7] Kotler, Philip dan Gary Armstrong (2008), Prinsip-Prinsip Pemasaran, Edisi 12, Jilid 1, Terjemahan oleh Bob Sabran, M.M, Jakarta: Penerbit Erlangga.

[8] Kotler, Philip dan Gary Armstrong 2012, Principles of Marketing: Global Edition Limited.

[9] Lawrence J. Gitman, 2003 Principles of Managerial Finance, edisi 10, Harper and Row Publishers, New York.

[10] Mohamad Mahsun.2006. Pengukuran Kinerja Sektor Publik, BPFE.

[11] Sattar, Mian Usman dan Beenish Sattar 2012."Customer Satisfaction Affects the Customer Loyalty: Evidence from Telecommunication Sector in Pakistan" Asian Journal of Business Management Vol.4 No.3 pp.252-259.

[12] Supranto, J. 2011. Pengukuran Tingkat Kepuasan Pelanggan, Jakarta, Rineka Cipta.

[13] Wheelen, Thomas L. and J. David Hunger .2000. Strategic Management \& Business Policy, 7th ed., Prentice-Hall 